\title{
室内斜視の場合の大をさと形 の恒常視に関する実験的研究
}

\section{1. 序一目 的}

壁、床、天井の栐な単一体の平面の大きさと形の恒常 視については、既飞研究を行い発表した通りである(1)， (2),(3)。即ち、一般江知覚像は真図より小さいが網膜像上 り大きく、正恒常となる。たとえば壁の場合は第 1 図の (1) の様になり、天井や床 の場合には第1図の (2),

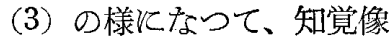
性何れ子真図と網膜像と飞 囲まれた斜線領域に在る。 図中の $H$ そは大きさの恒 常視が現わ机、 $G, I, J$ 飞は 形の恒常視が現われる。添 字の $s$ は網膜像、 $p$ は知覚 像を表方するのとする。

それでは、こういう単一 体の平面がいくつか組合わ された複合体即ち立体はぞ うなるであろうか。二つの 壁が組合わされた場合即ら 直六面体のビルを外からみ た場合については、発表し
(1)

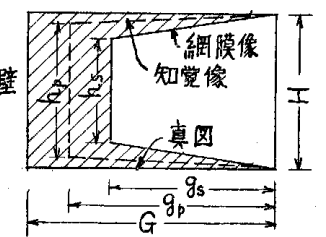

(2) 天
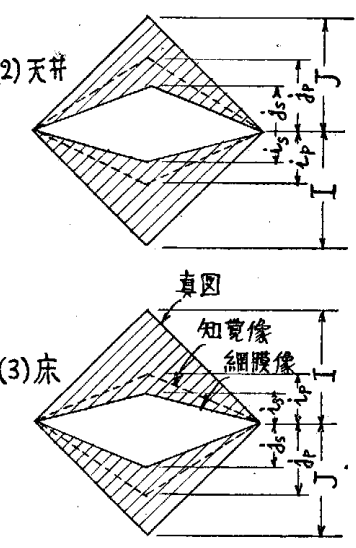

第 1 図 単一体の知覚像 $た^{(6)}$ 。三つの壁と床と天井が組合わされた場合即ち室内 を正視する場合についてる、矢の一部を発表した(4),(7)， (8)。そこでこの研究湉いては、二つの壁と床と天井が 組合わされた場 合、即ち第 2 図の 様煌内室内以る 人が室の隅を斜め $45^{\circ}$ 方向からみる 場合を実験した。

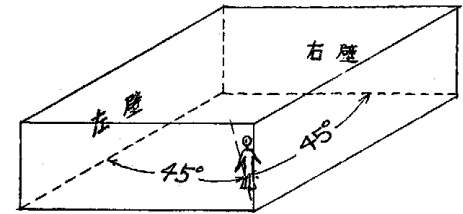

第 2 図 室内斜視の観測位置
これを室内斜視と呼ぶことにする。この時の知覚像は第 3 図の様になる。左右の壁の $g_{p}$ に注形の恒常視が現わ れ、 $h_{p}$ には大きさの恒常視が現われるであるろし、床、 天井の $i_{D}$ 之 $j_{p}$ には形の恒常視が現われるであるう。 だから、るし、壁、床、天井を別々飞分解して考党る

* 建築に招ける大きさと形の恒常視に関する䒠験的研 究第八 (文献参照)

訂正一同上第七、横長長方形壁の大きさと形の恒常 視飞関する実験的研究（建築学会論文報告集第 58 号）は、同上第六の誤である。

**熊本大学教授
正会員黒田正 巳苂

と、それらの知覚 像は網膜像上り大 きいので、第 4 図 の様になつて、入 隅の稯線は交互に 食いちがうはずで ある。併し複合さ れた室全体の知覚 像は食いちがわな いで、第 3 図の様 になる。従つて、 知覚像飞抒ける $w x y z$ の团む長方 形が、真の室の $W X Y Z$ 之相似形 である、と仮定す る限り、壁湾は、 $h_{p}$ 飞大きさの恒 常視が現わ礼るだ けで、形の恒常視 は現われないとみ るべきである。或 は、左右の壁の形 の恒常視が相反す る方向から同じ強
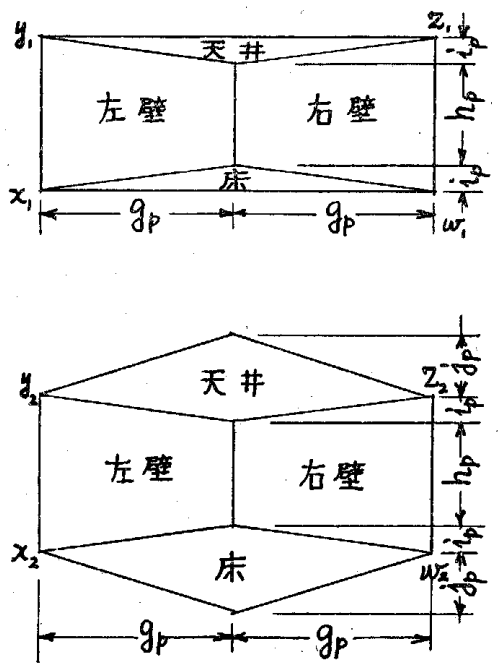

（上）床、天井の半分をみる場合 （下）床、天井の全部をみる場合

第 3 図室内斜視の知賞像

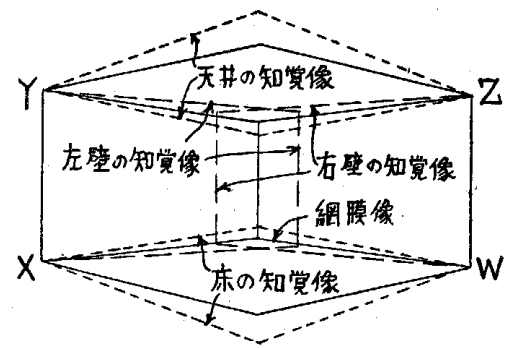

第 4 図壁、林、天井を分解 した場合の知覚像

さで競合しているので、互に釣合を保つている、或は相 殺している、と考兄てもよい。床と天井には、 $i_{p}$ と $j_{p}$ 飞形の恒常視が現われて、何れ子網膜像よりも大きくな ろうとする。一方、壁の $h_{p}$ も大きくなるうとするので、 $i_{p}$ と $h_{p}$ との間には力の競合が起ることになる。

この様蛋複合体の各種の恒常視の競合、相反、釣合と いつた様な相互関係の状態を明らか沉することを目的と したものがこの研究である。先に述べた様に、壁の $g_{p}$ は変化しないので、 $h_{p}$ の変化だけを明らかにすればよ い。既に研究した結果から、室の形は $h_{p}$ 亿影響を与兄 ないと考えられるので、観測距離の与兄る影響だけをみ た。但し、観測距離が変ることは同時に観測偏角が変る ことになるが、一応、前者だけで表わすことにした。

\section{2. 方 法}

写真に示す様な室を対象とする。この平面は辺長 7.12 $\mathrm{m}$ の正方形で、高さは $3.15 \mathrm{~m}$ である。この寸法は内法 


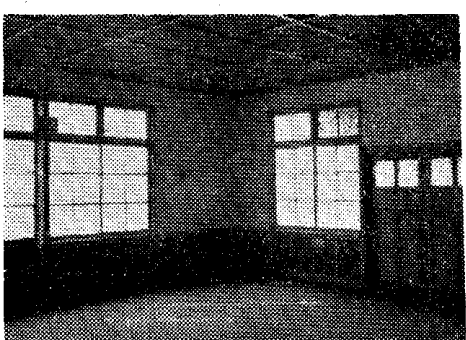

写真 実験対象

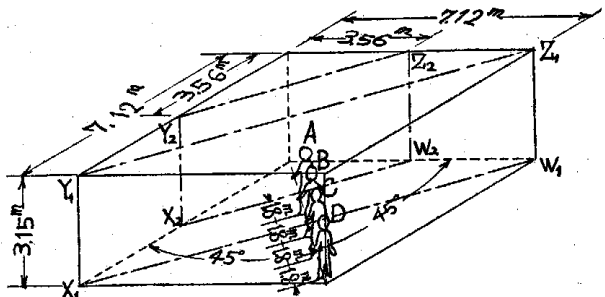

第 5 図 床、天井の半分をみる場合の 観測位置

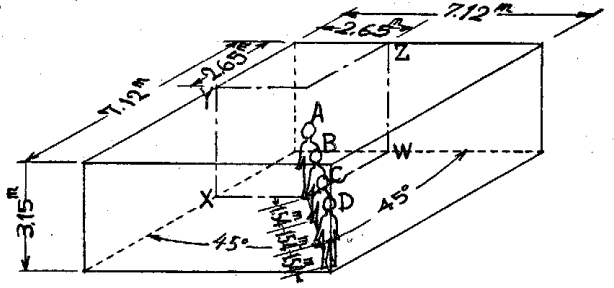

第 6 図 床、天井の全部をみる場合 の観测位置
である。この室は現在の熊本大学工学部建築科彫塑室で ある。第 3 図の上の様沐、天井の半分を及る場合、即 ら床、天井の形が三角形となる場合と、第 3 図の下の様 飞床、天井の全部をみる場合、即ち床、天井が紙窵形と なる場合との二つの場合について実験したが、前者は更 K、外郭線が大小二つの場合、即ち長方形 $W_{1} X_{1} Y_{1} Z_{1}$ 及び長方形 $W_{2} X_{2} Y_{2} Z_{2}$ の場合について行つた。第 5 図、 第 6 図に示す通りである。図の中の鎖線が第 3 図の外郭 線に相当するもので、これは実際には、巾 $1.9 \mathrm{~cm}$ の色 テープを床、壁、天井に張り趈したるのである。

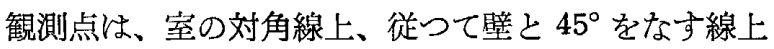
にあつて、その距離は、㦿、天井の半分をみる場合は、 テープ枠から $1.8 \mathrm{~m}$ ずつを保つ $A, B, C, D$ の四点、床、 天井の全部をみる場合は、色テープ枠から $1.54 \mathrm{~m}$ ずつ を保つ $A, B, C, D$ の四点である。但し、 $W_{1} X_{1} Y_{1} Z_{1}$ の場 合壮 $A$ を欠ぐ。観測点の高さは室の高さの中央である から、起立した成人の眼の高さに近い。

被験者は熊本大学工学部貄築学科学生 19 名及び 17 名 である。床、天井の半分をみる場合の実験は、その大小 二つの場合と、他の実験(币 5 間の室を正視する場合 ${ }^{(8)}$ ) とを相前後して連続 1 回に行つた。但し、その順序は不 規則である。床、天井の全部をみる場合はそれだけを1 回に行つた。観測点順は両方とも不規則とする。但し、 その順序が一方に 偏しないで一様に 分布する様にし た。

選択法による。 選択図は、床、天井 の半分をみる場合 性第 7 図之第 8 図 の通りである。即 ち、外郭線は真の 形と相似形の一定 のものとして、 $h_{p}$ だけが、 $2 \mathrm{~mm}$ 及 び $4 \mathrm{~mm}$ の歩みを もつて変化する多 数の図形である。

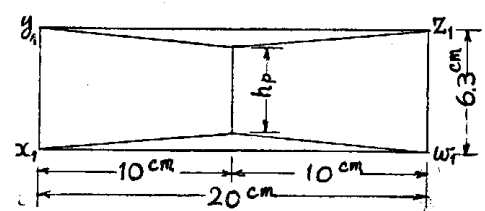

第 7 図、床、天井の半分をみる 場合（大）の選択図 $h_{p}=55,53,51,47,43,39$, $35,31,27,23,19,15 \mathrm{~mm}$

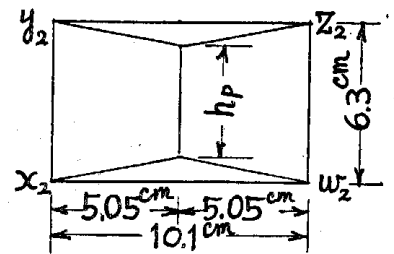

第 8 図 床、天井の半分をみる 場合（小）の選択図 $h_{p}=55,53,51,47,43$, $39,35,31,27 \mathrm{~mm}$
床、天井の全部をみる場合の選択図は第 9 図と第 1 表に 示す様に、外郭線相当の形の長さ注一定で、 $1.0 \mathrm{~cm}$ から $2.5 \mathrm{~cm}$ に至る 7 種の $i$ のそ れぞれについて 5 種乃至 6 種 ずつの $j$ をつ 36 種の図形 である。この $i$ の歩みは 2.5 $\mathrm{mm}$ で、 $j$ の歩みは $10 \mathrm{~mm}$ である。これらの図形はすべ $\tau 19 \mathrm{~cm} \times 27 \mathrm{~cm}$ の白画用 紙に黒線をむつて、一枚に一 図形ずつ描いたものである。

被験者炕与党る指示は「指 定された観测点に立つて色テ

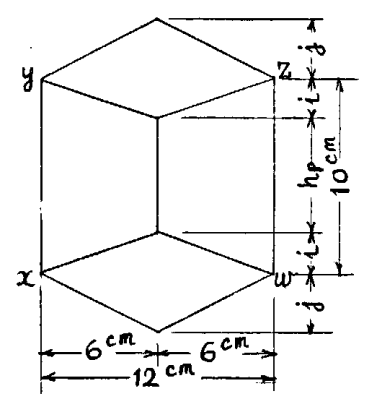

第 9 図 林、天井の全 部をみる場合 の選択図
ープから向う側をみなさい。みえの形に最も近い図形を これらの選択図の中から、一つだけ選出しなさい」とい

第 1 表 床、天井の全部をみる場合の選択図 の大きさ $(\mathrm{cm})$

\begin{tabular}{|c|c|c|c|c|c|c|c|}
\hline$i$ & $j$ & $i$ & $j$ & $i$ & $j$ & $i$ & $j$ \\
\hline 2.50 & $\begin{array}{l}2.50 \\
3.50 \\
4.50 \\
5.50 \\
6.50\end{array}$ & 2.00 & $\begin{array}{l}2.00 \\
3.00 \\
4.00 \\
5.00 \\
6.00 \\
7.00 \\
\end{array}$ & 1.50 & $\begin{array}{l}1.50 \\
2.50 \\
3.50 \\
4.50 \\
5.50\end{array}$ & 1.00 & $\begin{array}{l}1.00 \\
2.00 \\
3.00 \\
4.00 \\
5.00\end{array}$ \\
\hline 2.25 & $\begin{array}{l}2.25 \\
3.25 \\
4.25 \\
5.25 \\
6.25\end{array}$ & 1.75 & $\begin{array}{l}1.75 \\
2.75 \\
3.75 \\
4.75 \\
5.75\end{array}$ & 1.25 & $\begin{array}{l}1.25 \\
2.25 \\
3.25 \\
4.25 \\
5.25\end{array}$ & & \\
\hline
\end{tabular}

第 2 表 林、天井の半分をみる場合の実㩆結果 $\left(h_{p}\right.$ の長さ $\left.\mathrm{cm}\right)$ ゴチックは個人差大なるもの、イタリックは網膜像に近いもの

\begin{tabular}{|c|c|c|c|c|c|c|c|c|c|c|}
\hline \multirow{2}{*}{$S$} & \multirow{2}{*}{ 順序 } & \multicolumn{4}{|c|}{$W_{1} X_{1} Y_{1} Z_{1}$ （大） } & \multicolumn{5}{|c|}{$W_{2} X_{2} Y_{2} Z_{2}$ (小) } \\
\hline & & 順序 & B & C & D & 順 序 & A & B & C & D \\
\hline $\begin{array}{l}\text { 坂本 } \\
\text { 窴 } \\
\text { 鼌 } \\
\text { 大園 } \\
\text { 大園 }\end{array}$ & $\begin{array}{l}\text { 小大 } \\
\text { 夵 } \\
\text { 小大 } \\
\text { 小无 } \\
\text { 大小 }\end{array}$ & $\begin{array}{l}\text { DBC } \\
\text { CBD } \\
\text { CBD } \\
\text { CDB } \\
\text { DCB }\end{array}$ & $\begin{array}{l}27 \\
35 \\
23 \\
27 \\
27\end{array}$ & $\begin{array}{l}39 \\
39 \\
27 \\
39 \\
31\end{array}$ & $\begin{array}{l}31 \\
43 \\
31 \\
47 \\
39\end{array}$ & $\begin{array}{l}\text { ABCD } \\
\text { DBAC } \\
\text { BDCA } \\
\text { BCAD } \\
\text { ACDB }\end{array}$ & $\begin{array}{l}31 \\
35 \\
35 \\
31 \\
27\end{array}$ & $\begin{array}{l}39 \\
39 \\
39 \\
39 \\
31\end{array}$ & $\begin{array}{r}35 \\
43 \\
43 \\
47 \\
35\end{array}$ & $\begin{array}{l}35 \\
43 \\
47 \\
47 \\
39\end{array}$ \\
\hline $\begin{array}{l}\text { 薢田 } \\
\text { 草 } \\
\text { 筷野 } \\
\text { 䏿田 }\end{array}$ & $\begin{array}{l}\text { 小大 } \\
\text { 小犬 } \\
\text { 尖小 } \\
\text { 犬小 }\end{array}$ & $\begin{array}{l}\text { BCD } \\
\text { DCB } \\
\text { CDB } \\
\text { DBC } \\
\text { DCB }\end{array}$ & $\begin{array}{l}19 \\
23 \\
27 \\
19 \\
23\end{array}$ & $\begin{array}{r}27 \\
31 \\
27 \\
23 \\
27\end{array}$ & $\begin{array}{r}35 \\
35 \\
31 \\
27 \\
35\end{array}$ & $\begin{array}{l}\text { CDAB } \\
\text { DCAB } \\
\text { DABC } \\
\text { ADCB } \\
\text { DACB }\end{array}$ & $\begin{array}{l}27 \\
27 \\
31 \\
27 \\
35\end{array}$ & $\begin{array}{l}35 \\
35 \\
35 \\
31 \\
39\end{array}$ & $\begin{array}{l}31 \\
35 \\
39 \\
39 \\
39\end{array}$ & $\begin{array}{l}43 \\
39 \\
39 \\
43 \\
47\end{array}$ \\
\hline 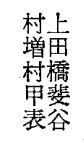 & $\begin{array}{l}\text { 小大 } \\
\text { 小大 } \\
\text { 小大 } \\
\text { 大小 } \\
\text { 天小 }\end{array}$ & $\begin{array}{l}\mathrm{CDB} \\
\mathrm{DBC} \\
\mathrm{BCD} \\
\mathrm{CDB} \\
\mathrm{BDC}\end{array}$ & $\begin{array}{l}19 \\
23 \\
19 \\
23 \\
23\end{array}$ & $\begin{array}{r}23 \\
27 \\
23 \\
27 \\
27\end{array}$ & $\begin{array}{r}15 \\
31 \\
27 \\
31 \\
31\end{array}$ & $\begin{array}{l}\text { BDAC } \\
\text { CADB } \\
\text { CBAD } \\
\text { BDCA } \\
\text { ABDC }\end{array}$ & $\begin{array}{r}27 \\
31 \\
27 \\
31 \\
31\end{array}$ & $\begin{array}{l}31 \\
35 \\
31 \\
35 \\
35\end{array}$ & $\begin{array}{l}43 \\
39 \\
35 \\
47 \\
39\end{array}$ & $\begin{array}{l}47 \\
47 \\
35 \\
51 \\
43\end{array}$ \\
\hline 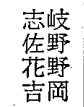 & $\begin{array}{l}\text { 大小 } \\
\text { 尖 } \\
\text { 冭 } \\
\text { 大小 }\end{array}$ & $\begin{array}{l}\text { CBD } \\
\text { BCD } \\
\text { CBD } \\
B C D\end{array}$ & $\begin{array}{l}27 \\
27 \\
23 \\
31\end{array}$ & $\begin{array}{l}31 \\
35 \\
31 \\
31\end{array}$ & $\begin{array}{l}39 \\
39 \\
35 \\
27\end{array}$ & $\begin{array}{l}\text { BCDA } \\
\text { CDBA } \\
\text { ACBD } \\
\text { CABD }\end{array}$ & $\begin{array}{l}35 \\
31 \\
31 \\
35\end{array}$ & $\begin{array}{l}43 \\
39 \\
35 \\
35\end{array}$ & $\begin{array}{r}47 \\
43 \\
39 \\
39\end{array}$ & $\begin{array}{r}51 \\
47 \\
43 \\
39\end{array}$ \\
\hline 平场㘬膜像 & & & $\begin{array}{l}24.48 \\
11.62\end{array}$ & $\begin{array}{l}29.74 \\
23.26\end{array}$ & $\begin{array}{l}33.21 \\
30.6\end{array}$ & & $\begin{array}{l}30.7 \\
26.2\end{array}$ & $\begin{array}{l}35.6 \\
27.3\end{array}$ & & $\begin{array}{l}43.42 \\
46.24\end{array}$ \\
\hline
\end{tabular}


第 3 表 休、天井の全部をみる場合の実験結果 $(\mathrm{cm})$

ゴチックは個人差大なるもの、イタリックは綱膜像に近いもの

\begin{tabular}{|c|c|c|c|c|c|c|c|c|c|}
\hline \multicolumn{2}{|c|}{$S \quad$ 観測点 } & \multicolumn{2}{|c|}{ A } & \multicolumn{2}{|c|}{ B } & \multicolumn{2}{|c|}{ C } & \multicolumn{2}{|c|}{ D } \\
\hline 娃 & 順 序 & $i$ & $j$ & $i$ & $j$ & $i$ & $j$ & $i$ & $j$ \\
\hline 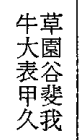 & $\begin{array}{l}\text { DCBA } \\
\text { BDAC } \\
\text { ABDC } \\
\text { DBCA } \\
\text { CBAD }\end{array}$ & $\begin{array}{l}2.25 \\
2.25 \\
2.50 \\
2.50 \\
1.75\end{array}$ & $\begin{array}{l}5.25 \\
6.25 \\
6.50 \\
6.50 \\
5.75\end{array}$ & $\begin{array}{l}2.00 \\
1.50 \\
2.25 \\
1.50 \\
2.00\end{array}$ & $\begin{array}{l}5.00 \\
4.50 \\
5.25 \\
5.25 \\
5.00\end{array}$ & $\begin{array}{l}1.25 \\
1.25 \\
1.25 \\
1.25 \\
1.50\end{array}$ & $\begin{array}{l}3.25 \\
2.25 \\
3.25 \\
2.25 \\
3.50\end{array}$ & $\begin{array}{l}1.10 \\
1.50 \\
1.50 \\
1.00 \\
1.25\end{array}$ & $\begin{array}{l}2.00 \\
1.50 \\
2.50 \\
2.00 \\
3.25\end{array}$ \\
\hline $\begin{array}{l}\text { 會原 } \\
\text { 坆本 } \\
\text { 角 } \\
\text { 藏田 }\end{array}$ & $\begin{array}{l}\text { CDAB } \\
\text { ABCD } \\
\text { DABC } \\
\text { CBDA } \\
\text { ACBD }\end{array}$ & $\begin{array}{l}2.00 \\
2.00 \\
2.50 \\
1.75 \\
2.25\end{array}$ & $\begin{array}{l}7.00 \\
5.00 \\
6.50 \\
5.75 \\
5.25\end{array}$ & $\begin{array}{l}2.00 \\
2.25 \\
1.75 \\
2.50 \\
2.25\end{array}$ & $\begin{array}{l}3.00 \\
2.25 \\
4.75 \\
4.50 \\
4.25\end{array}$ & $\begin{array}{l}1.75 \\
2.25 \\
1.50 \\
1.50 \\
2.50\end{array}$ & $\begin{array}{l}3.75 \\
4.25 \\
2.50 \\
2.50 \\
4.00\end{array}$ & $\begin{array}{l}1.25 \\
1.75 \\
1.25 \\
1.25 \\
1.00\end{array}$ & $\begin{array}{l}2.25 \\
2.75 \\
2.25 \\
3.25 \\
2.00\end{array}$ \\
\hline $\begin{array}{l}\text { 本真 } \\
\text { 喜 } \\
\text { 前墳卡 } \\
\text { 增田 }\end{array}$ & $\begin{array}{l}\text { BCDA } \\
\text { BADC } \\
\text { BCAD } \\
\text { ACDB } \\
\text { CADB }\end{array}$ & $\begin{array}{l}2.00 \\
1.50 \\
2.00 \\
2.00 \\
1.75\end{array}$ & $\begin{array}{l}7.00 \\
5.50 \\
5.00 \\
7.00 \\
\mathbf{3 . 7 5}\end{array}$ & $\begin{array}{l}1.50 \\
1.75 \\
2.25 \\
1.75 \\
1.50\end{array}$ & $\begin{array}{l}4.50 \\
5.75 \\
5.25 \\
4.75 \\
5.50\end{array}$ & $\begin{array}{l}1.00 \\
1.50 \\
1.25 \\
1.75 \\
1.25\end{array}$ & $\begin{array}{l}4.00 \\
4.00 \\
3.25 \\
3.75 \\
4.25\end{array}$ & $\begin{array}{l}1.25 \\
1.25 \\
1.00 \\
1.25 \\
1.00\end{array}$ & $\begin{array}{l}3.25 \\
3.25 \\
4.00 \\
2.25 \\
3.00\end{array}$ \\
\hline $\begin{array}{l}\text { 村橋 } \\
\text { 知野 }\end{array}$ & $\begin{array}{l}\text { ADCB } \\
\text { BDCA }\end{array}$ & $\begin{array}{l}2.00 \\
2.00\end{array}$ & $\begin{array}{l}7.00 \\
7.00\end{array}$ & $\begin{array}{l}1.50 \\
1.75\end{array}$ & $\begin{array}{l}5.50 \\
4.75\end{array}$ & $\begin{array}{l}1.50 \\
1.25\end{array}$ & $\begin{array}{l}4.50 \\
3.25\end{array}$ & $\begin{array}{l}1.00 \\
1.25\end{array}$ & $\begin{array}{l}3.00 \\
2.25\end{array}$ \\
\hline 網朐膜像 & & $\begin{array}{l}2.059 \\
2.520\end{array}$ & $\begin{array}{c}6.000 \\
\infty\end{array}$ & $\begin{array}{l}1.882 \\
1.786\end{array}$ & $\begin{array}{l}4.647 \\
6.133\end{array}$ & $\begin{array}{l}1.471 \\
1.383\end{array}$ & $\begin{array}{l}3.471 \\
3.067\end{array}$ & $\begin{array}{l}1.221 \\
1.129\end{array}$ & $\begin{array}{l}2.632 \\
2.044\end{array}$ \\
\hline
\end{tabular}

う。系列法による。両眼視とする。

\section{3. 結 果}

選出された長さ即台知覚像の長さは、第 2 表と第 3 表 の通りである。表中に観測順序と網膜像を併記した。こ こで、網膜像の投射面は、観测点の並ぶ線に直角の方向 の鉛直面とした。従つて、壁、床、天井の個々の単一体 をみる場合のそれと違つているので、網膜像の形る少し らがつていることになる。

観測距離が小さい時は、視野が大きいので、観測が困 難であることを訴えた者が多からた。そして、その時は 視線の方向以よつてみえの形が異ることを訴えたものも 数名めつた。たとえば、暨だけをみると $h_{p}$ は大きくみ えるが、床や天井だけをみると $i_{p}$ が大きくみ元るので $h_{p}$ は小さくなるという様な訴觉である。又、床、天井 の半分をみる場合に、壁の手前近くに視線があるときは 色テープの形造る床と天井の平行なるべき線が、平行で はなくて先つぼまりに傾いてみ方るという訴えもある。 これらのととは、外郭線の形を真の形と相似形としたこ とにる原因があると考光られるが、複合体の害験が本来 困難なるのであることを示するのであろう。
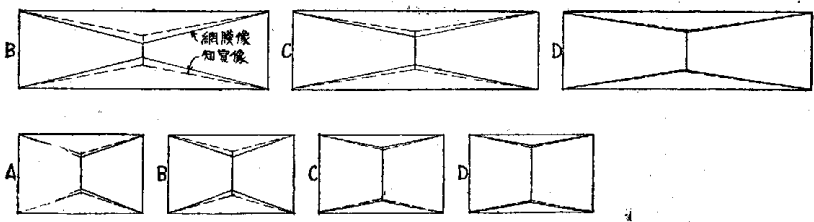

第 10 図 床、天井の半分をるる場合の実験結果の平均

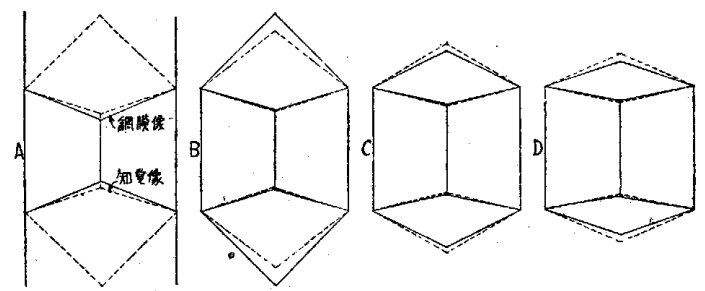

第 11 図 床、天井の全部をるる場合の 実験結果の平均
第 2 表、第 3 表の平均を図示すれ第 10 図、第 11 図 を得る。

\section{4. 考 察}

表によつてみると、個人差の大きい数ね少ない。網膜 像に近いものが多い。第 10 図、第11 図によつてみると 観測距離の小さい少数の点を除くなら、一般に網膜像に 極めて近い。従つて恒常度は少さいといえる。

（1） 床、天井の半分をるる場合

観測距離が小さい時は、 $h_{p}$ は $h_{s}$ より大きいが、距離 が大きくなるに従つて連続的に小さくなり、つい逆に $h_{s}$ より小さくなる。逆転する時が $h_{p}$ と $h_{s}$ が等しい時 である。つまり、壁の大きさの恒常度は、観測距離が大 きくなるに従つて、連続的に正より零を経て負に至るこ とになる。床、天井の $i_{p}$ はこれと逆の変化をするので、 床、天井の形の恒常度は、観測距離が大きくなるに従つ て、連続的に負より零を経て正に至ることになる。従つ て、壁の大きさの恒常視と、床、天井の形の恒常視は相 互に競合するが、観測距離が小さい時は前者が後者より 優勢であるが、距離が大きくなるに従つて、両者が釣合 つた点を過ぎ、後には逆に後者が優勢となる、というこ とができる。しかもこの変化は連絸的である。

両者が釣合つた点恃、知覚像が網膜像に一致した点で あるから、この点を視点として従来の普通透視図を描け ば、それは知觉像江等しい透視図即ち知覚透視図となる はずである。この点は、 $W_{1} X_{1} Y_{1} Z_{1}$ の場合は $D$ 亿近い 点であり、 $W_{2} X_{2} Y_{2} Z_{2}$ の場合は $A$ と $B$ の中間の点であ るが、それは、WXYZ と室隅との距離江近い。或はこ の点恃視角 $90^{\circ}$ 亿相当し、乙かもこれを越えても大きな 変化は夕られないので、簡易実用法としては、視角 $90^{\circ}$ 以下の点を視点として、普通透視図を描けげよいことに なる。

（2）床、天井の全部をみる場合

$h_{p}$ と $i_{p}$ そつては、床、天井の半分をみる場合と大 体同じ傾向示す。即ち、観測距離が大きくなるに従つ て、壁の大きさの恒常度は、正より零を経て負江至り、 床、天井の $i_{p}$ の形の恒常度は負より零を経て正江至る。 $j_{p}$ の変化は $i_{p}$ と同じ傾向を示すけれども、変化の 量は異り、網膜像に一致する点も同じではない。即ち、 両者の変化は平行しないのである。従つて、すべての恒 常度が一致して共に零となる様な観測点は存在しない。 併しそれらが零に近くなる観测点が在るから、ここを視 点として普通透視図を描梳ばよい。この点は $B$ と $C$ との 中間であつて、大体、室の対角線の 7 割位の点である。 これは視角 $45^{\circ}$ そ近く、しかもこれを越えても大きなち がいがないので、簡易実用法としては、視角 $45^{\circ}$ 以下の 点を視点として普通透視図を描けばよいことになる。

\section{5. 結 論}

（1） 床、天井の半分をみる場合 
1. 壁の形の恒常視は現われない。

2. 壁の大きさの恒常度は、観測距離が大きくなると 従つて、正より零を経て負に至る。

3. 床、天井の形の恒常度は 2 の逆となる。

4. 上の二つの恒常度が、共㴟零となる観測点は視角 $90^{\circ}$ の点である。

5. 視角 $90^{\circ}$ 以下の点を視点として普通透視図を摆け ば知覚透視図となる。

6. 恒常度は概して小さい。

2,3,4 から次の様狺うこともできる。

7. 壁の大きさの恒常視と、床、天井の形の恒常視は 競合し、観測距離が小さい時は前者が優勢であるが、そ れが大きくなるに従つて、両者が釣合う点を通り、後に は逆に後者が優勢となる。

（2）床、天井の全部をみる場合

1. 壁の形の恒常視は現われない。

2. 壁の大きさの恒常度は、観測距離が大きくなると 従つて、正より零を経て負に至る。

3. 床、天井の形の恒常度は 2 の逆となる。

4. 上の二つの恒常度が、零に近くなる観測点は視角 $45^{\circ}$ の度である。

5. 視角 $45^{\circ}$ 以下の点を視点として普通透視図を描け ば知覚透視図となる。

$2,3,4$ から次に言うこともできる。

6. 壁の大きさの恒常視と、床、天井の $i$ の形の恒常 視は競合し、観測距離が小さい時は、前者が優勢である が、それが大きくなると従つて、両者が釣合う点を通
り、後には逆に後者が優勢となる。

実験の一部協力した学生久我隆一氏と、被験者とな つた学生譇氏に感謝する。

[文 献]

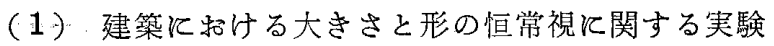
的研究第一、水平面正方形図形の場合、日本建築 学会論文報告集、第 54 号、昭和 31 年 9 月

（2）同上第二、網膜像の作図及び凝視点がある場合 の知覚像、日本建築学会論文報告集、第 55 号、 昭和 32 年 2 月

（3）同上第三、鉛直面正方形図形の場合、日本建築 学会論文報告集、第 56 昂、昭和 32 年 6 月

（4）同上その 1 、嫏下の場合、日本建筑学会研究報 告、第 33 号、昭和 30 年 10 月

（5）同上その 5、高い建物を近い正面から見上げる 場合、日本建筑学会九州交部研究報告、第 6 号、 昭和 32 年 2 月

（6）同上第四、直六面体の建築を外からみる場合、 日本建築学会論文報告集、第 57 号、昭和 32 年 7 月

（7）同上その6 抄、普通廊下と㑡壁のない廊下との 比較、日本心理学会第 21 回大会発表論文抄録、 昭和 32 年 10 月

（8）同上第五抄、室内正視その 1 、日本建築学会九 州支部研究壁告、第 7 号、昭和 32 年 11 月

（9）同上第六、横長長方形壁の大きさと形の恒常視 飞関する実験的研究、日本建築学会論交報告集、 第 58 号、昭和 33 年 2 月

(10) 同上第七、対向壁の平行知覚飞関する実験的研 究、日本建築学会論交報告集、第 59 号、昭和 33 年 6 月 